\title{
AKTIVITAS ENZIM CARBOXY METHIL. CELLULASE DAN PRODUKSI VOLATILE FATTY ACID PADA FERMENTASI SELULOSA OLEH MIKROBIA RUMEN SECARA IN VITRO
}

\author{
Nafiatul Umami, Zaenal Bachruddin dan Hari Hartadi'
}

\section{INTISARI}

Penelitian ini bertujuan untuk mengetahui pengaruh penambahan arang aktif (AA) pada fermentasi mikrobia rumen secara in vitro. Penclitian dilakukan dalam dua tahap yaitu, Tahap I menggunakan substrat kertas saring dengan level AA yang berbeda yaitu $0 \% ; 0,3 \%, 0,6 \% ; 0,9 \%$ dan keempat perlakuan diamati $\mathrm{pH}$ dan aktivitas cnzim carboxy methil cellutase (CMC-ase)nya pada jam ke-24, 96 dan 144. Tahap 11 merggunakan kadar AA terbaik untuk empat macam perlakuan: perlakuan I 10\% kertas saring dan 90\% glukosa, perlakum II 20\% kertas saring dan $80 \%$ glukss, putlakuan III $30 \%$ kertas saring dan $70 \%$ glukosa dan perlakuan TV $90 \%$ kettas saring dan 10\% glukosa, pengambilan sampel pada jarn ke-0 dan ke-6. Variabel yang diamati adalah nilai $\mathrm{pH}$, aktivitas enzim $\mathrm{CMC}$-ase dan produksi volatile fatty acid meliputi asetat $\left(\mathrm{C}_{2}\right)$, propionat $\left(\mathrm{C}_{4}\right)$ dan butirat $\left(\mathrm{C}_{4}\right)$. Data yane diperoleh dari raneangan acak lengkap pola tersarang dianalisis dengan menggumakan analisis variansi, perbedaan variabel karena perlakuan diuji dengan Duncan's Multiple Range Test (DMRT). Hasil penelitian menunjukkan bahwa secara rerata aktivitas enzim CMC-ase tertinggi pada penambaham $\mathrm{AA} 0,3 \%$ menunjukkan hasil tertinggi dari aktivitas $C M C$-ase secara rerata dengan pengaruh yang nyata $\mathrm{P}<0,05$ pada inkubasi jam ke-96 dari tiap perlakuan, dan pada tahap kedua dengan AA 0,3\% aktivitas tertinggi pada perlakuan II glukosa $80 \%$ dimana aktivitas CMC-ase $93,67 \mathrm{mgD}$-glukosa/ $\mathrm{mg}$ prot alb. Kadar volatile fatty acid (VFA) terutama rasio $\mathrm{C}_{2}$ dan $\mathrm{C}_{3}$ berturut-turut $3,28,3,27,8,36$ dan 16,29 menunjukkan perbedaan yang nyata $\mathrm{P}<0,05$ perlakuan I, II dengan periakuan III, IV. Terlihat bahwa dengan penambahan glukosa menyebabkan semakin kecilnya rasio $\mathrm{C}_{2}: \mathrm{C}_{3}$. Hal ini dikarenakan semakin meningkatnya produksi propionat $\left(C_{3}\right)$.

(Kata kunci: Arang aktif, Fermentasi mikrobia rumen, fn vitro. $\mathrm{pH}, \mathrm{CMC}$-ase, Volatile fatty acid)

\footnotetext{
${ }^{2}$ Fakultas Peternakan Universitas Gadjah Mada, Yogyakarta
} 


\title{
ACTIVITIES OF CARBOXY METHIL CELLULASE AND VOLATILE FATTY ACID PRODUCIION ON IN VITRO CELLULOSE FERMENTATION BY RUMEN MICROBIA
}

\begin{abstract}
The objective of this study was to determine the effect of activated charcoal (AC) addition in the medium on the rumen microbial fermentation with in vitro method. The first study had used fitter paper as carbon source with different levels of $\mathrm{AC}$ namely $0 \% \mathrm{AC}, 0.3 \% \mathrm{AC}, 0.6 \% \mathrm{AC}$ and $0.9 \% \mathrm{AC}$. The variables of this study were $\mathrm{pH}$ value and $\mathrm{CMC}$-ase activity. The second study used the best level of $\mathrm{AC}$ from the first study and using filter paper and glucose of four differrent levels as carbon sources. The respective levels were namely I 10\% filter paper and $90 \%$ glucose, $1120 \%$ filter paper and $80 \%$ glucose, III $30 \%$ filter paper and $70 \%$ glucose and IV $90 \%$ filter paper and $10 \%$ glucose. Fach treatment was done in 3 replications. The variables being measured in this study were $\mathrm{pH}$ values, CMC-ase activity and volatile fatty acid (VFA) production. The obtained data were analyzed by analysis of variance following completely randomized design and the different variable values affected by treatments were analysed by Duncan's New Multiple Range Test (DMRT). The result of the first study showed that CMC-ase activities was highest $(\mathrm{P}<0.05)$ with addition of $0.3 \% \mathrm{AC}$. On the second study, addition of $0.3 \% \mathrm{AC}$ caused the highest $\mathrm{CMC}$ ase activity when level of glucose was $80 \%$ with $20 \%$ filter paper as the substrate $(83.67 \mathrm{mg} \mathrm{D}$ glucose/mg prot alb.). The statistical analysis resulted no significant effect between glucose levels on ruminal fermentation acidity $(\mathrm{pH})$. The volatile fatty acid especially $\mathrm{C}_{2}: \mathrm{C}_{3}$ ratio showed that 1 , II differed $(\mathrm{P}<0.05)$ with III, IV i.e. $3.2800,3.2729,8.3607$ and 16.2960 . The numbers showed that glucose addition decrease ratio of $\mathrm{C}_{2}: \mathrm{C}_{3}$ due to the increase of propionatc $(\mathrm{C} 3)$ production.
\end{abstract}

(Key words: Activated charcoal, Rumen microbial fermentation, $I n$ vitro, pH, CMC-asc, Volatile fatty acid)

\section{Pendahuluan}

Serbuk arang aktif (AA) merupakan feed additive termasuk kategori senyawa sederhana yang tidak mempunyai nilai nutrien. Peranan dari $\mathrm{AA}$ adalah mampu mengabsorpsi senyawa organik dan anorganik dan partikel yang bersifat koloidal. Arang aktif ini merupakan suatu senyawa amorf yang mempunyai luas permukaan yang besar. Luas pcrmukaan yang besar tersebut disebabkan adanya makropori dan mikropori pada arang aktif (Gray yang disitasi Witanti, 1992) dan mempunyai daya serap yang lebih besar dibanding arang yang tidak diaktivasi (Kirk Orthner yang disitasi Witanti, 1992).

Kumpulan ion $\mathrm{C}^{+}$yang ada dalam arang. aktif akan mengikat $\mathrm{H}$ yang banyak dihasilkan dari hidrolisis pati yang terkandung dalam konsentrat menjadi asam laktat. Pemberian pakan dengan kandungan. konsentrat tinggi akan menyebabkan konsentrasi ion $\mathrm{H}$ meningkat sehingga akan menyebabkan penununan $\mathrm{pH}$, akan tetapi dengan penambahan AA maka akan teriadi pengikatan ion $\mathrm{H}^{-}$oleh ion $\mathrm{C}^{+}$sehingga $\mathrm{pH}$ rumen tetap stabil (Garillo et al., 1994).

Proses pemanfaatan pakan menjadi nutrien yang tersedia bagi ternak sangat didukung olch kegiatan mikrobia rumen (Kuswand3, 1993). Cairan rumen mengandung bakieri yang mampu menghasilkan enzim unuk memanfaatkan selulosa, hemisclulosa dan pati (Tillmanet ef al., 1991). Proses degradasi fermentatif atau pencernaan mikrobia pakan sebagian besar terjadi di rumen (Sutardi, 1978; Church, 1988). Produk fermentasi di numen dapat berupa asam format, asam asctat, asam propionat, asam butirat, asam laktat, hidrogen, $\mathrm{CO}_{2}$ dan ethanol (Lowe, 1986 yang disitasi oleh Kumiawati, 1999): Pada ruminansia, karbohidrat akan 
mengalamı fermentasi secara anacrobik schingga mengakibatkan jumlah produksı yang terbesar adalah VFA terutama asam asetat, usam propionat dan asam butirat, VFA yang diproduksi oleh aktivitas mikscorganisme menyediakan energi total yang terbesar yaitu lebih dari $14 \%$ dari kebutuhan encrgi untuk maintenance (Church and Ponds, 1982), Ranjham dan Pathak (1979) yang disitasi Kurniawati (1999) menyatakan bahwa adanya produk fermentasi yang beripa asam lemak volatil yang bersifa! asam akan menyebabkan $\mathrm{pH}$ rumen turun, absorbsi asm lemak volatil oleh dinding rumen akan turut mengatur $\mathrm{pH}$ rumen agar tetap padi kondisi yang optimal untuk herlangsungnya proses enzimatik dan terfermentasi oleh mikrobial. Banyak sedikitnya VFA, $\mathrm{CO}_{2}$ dan gas methan dipengaruhi oleh macam ransum yang diberikan. Ternak yang banyak mendapat pakan hijauan maka VFA yang terbanyak adalah asam asetat $(50-65 \%)$, disusul asam propionat (18-25\%) dan terakhir asam butirat (12-20\%). Pada keadaan pakan dengan konsentrat tinggi maka komposisi asetat turun sedangkan propionat naik (Tillman ot al., 1991).

Tinggi rendahnya $\mathrm{pH}$ cairan rumen merupakan salah satu faktor yang menentukat baik tidaknya proses fermentasi didalam numsen (Irianta, 1997), Nilai pH rumen sangat besar pengaruhina terhadap kelangsungan hidup mikrobia rumen (Davies, 1982).

Faktor-faktor yang menpengaruhi produksi dan aktivitas enzim selulase antara lain jenis dan kadar substrat, temperatur, $\mathrm{pH}$ dan inhibitor dari produk akhir (Enary, 1983 yang disitasi oleh Kumiawati, 1999). Produksi enzimi sclulase akan terjadi apabila mikrobia selulolitik tumbuh pada media yang mengandung substrat selulosa atau derivatnya. Proses pemccailan selulosa olch aktivitas enzim selulase sangat dipengaruhi olch struktur fisik dari substrat. Bentuk kristal pada umumnya lebih sulit daripada bentuk amorf (Church, 1988).
Proses degradas! selulosa secara biologis selalu menggunakan beberapa enzim selulase sebagai biokatalisator. Enzim scelulase merupakan nama umum bagi semua cnzim yeng dapat menghidrolisis ikatan $\beta-1,4$ glikosidik dalam selulosa, selodekstrin, selobiosa dan derivatif selulosa yang lain. Nama sistematik enzim selulase adalah $B-1,4$ glukan 4-glukanohidrolase (EC.3.2.1.4.). Enzim selulase sesungguhnya merupakan suatu enzim komplck yang terdiri dari beberapa enzim yang bekerja secara betahap atau bersama-sama manguraikan selulosa menjadi glukosa, Enzim selulase terdiri dari tiga komponen aktif, yaitu enzim ekso $\beta-(1,4)$ glukanase atau enzim $C 1$, endo $\beta-(1,4)$ glukanase atat sering discbut cnzim Carboxymethyl Celluiase (CMC-ase) atau enzim $\mathrm{Cx}$ dan cnzim B-glukosidase (Lehninger, 1997).

Penelitian ini bertujuan untuk mengetahui pengaruh penambahan karbohidrat nonstruktural dan arang aktif (AA) terhadap $\mathrm{pH}$, aktivitas enzim selulase, dan imbangan $\mathrm{C}_{2}: \mathrm{C}_{3}$ pada fermentasi selulosa oleh mikrobia rumen sapi secara in vitro.

Hasil penelitian ini diharapkann dapat memberikan informasi mengenai pเnganih pemberian arang aktif (AA) sebagai buffer terhadap fermentasi selulosa olch mikrobia rumen sapi secara in vitro, sehingga diharapkan mampu mempertahankan kondisi biokimiawi fermentasi olch mikrobia rumen yang meliputi $\mathrm{pH}$, aktivitas enzim selulase dan imbangan $\mathrm{C}_{2}: \mathrm{C}_{1}$.

\section{Materi dan Metode}

Penelitian ini meliputi dari dua tahap, Tahap pertama adalah pembuatan fermentasi mikrobia rumen dengan kadar substrat sama, yaitu: $100 \%$ kertas saring dan kadat arang aktif yang berbedn yaitu $0 \%, 0,3 \%, 0,6 \%$ dan $0,9 \%$ dari total substrat yang diberikan dalam rancangan acak lengkap masing-masing replikasi tiga kali, Kemudian dilihat aktivitas enzim $C M C$-asenya dan nilai $\mathrm{pH}$ pada lama inkubasi 24, 96 dan 144 jam. Tahap kedua 
penggunaan $\mathrm{A} A$ hasil terbaik percobaan tahap pertama dengan substrat kertas saring dan glukosa dengan imbangan sebagai berikut: I) $90 \%$ glukosa dan $10 \%$ kertas saring. H) $80 \%$ glukosa dan $20 \%$ kertas saring, III) $70 \%$ glukosa dan $30 \%$ kertas saring dan IV) $10 \%$ glukosa dan $90 \%$ kertas saring dengan rancangan acak lengkap, masing-masing tiga replikasi. Variabel yang diamati meliputi nilai $\mathrm{pH}$, akfivitas CMC-ase serta kadar volatile faty actd (VFA).

\section{Pembuatan medium basal}

Medium basal dibuat menurut metode Bachrudin (1996), sebagai berikut; didalam setiap $100 \mathrm{ml}$ medium fendiri dari 0,25 gram yeast ekstrak, I gram trypton, 0,49 gram $\mathrm{NaHCO}_{3}$, kemudian ditambah $15 \mathrm{ml}$ mineral I, $15 \mathrm{mi}$ mineral $1 \mathrm{I}$, aquades $40 \mathrm{ml}$ serta $30 \mathrm{ml}$ cairan rumen untuk medium basal. Semua bahan dalam erlenmeyer kemudian dididihkan. Proses pendidihan dilakukan sebanyak tiga kali dan selanjutnya segera tambahkan 0.1 gram cystein $\mathrm{HCl}$, untuk menghomogenkan komponen medium, sccara terus-menerus diletakkan di atas alat pengaduk magnetik secara elektrik dan kemudian dimasukkan ke dalam botol sebagai fermentor yang telah diisi dengan substrat $2 \%$ dari medium berupa glukosa dan kertas saring dengan kadar yang berbeda-beda dan juga arang aktif $0,3 \%$ dari substrat, Komposisi mineral I untuk $100 \mathrm{ml}$ adalah $0,3 \% \quad \mathrm{~K}_{2} \mathrm{HPO}_{4}$ dan untuk mineral II adalah $0,3 \% \mathrm{KH}_{2} \mathrm{PO}_{4}, 0,6 \%\left(\mathrm{NH}_{4}\right)_{2} \mathrm{SO}_{4}, 0,6 \%$ $\mathrm{NaCl}, 06 \%, \mathrm{MgSO}_{4}, 0,06 \% \quad \mathrm{CaCl}_{2}$ dalam $100 \mathrm{ml}$ aquades. Selanjutnya medium basal yang telah dimasukkan dalam botol fermentor ditutup dengan aluminium foil dan disterilisasi dengan autoklav (121 psi/ 15) menit. Segera setelah sterilisasi aluminium foil diganti dengan tutup karet steril dan diklem dengan tutup aluminium. Inokulasi sumber mikrobia yaitu caitan rumen sebanyak $10 \%$ dari total medium dalam fermentor

\section{Inkubasi medium dan pengambilan sampel Inkubasi dilakukan untuk mensimulasi} medium fermentast seperti kondisi di rumen pada subu $38-39^{\circ} \mathrm{C}$ sehingga pada medium fermentasi yang tefah diinokulasi mikrobia akan terjadi fermentasi substrat.

Tahap pertama medium fermentasi diambil sampel sebanyak $1,5 \mathrm{ml}$ pada jam ke24,96 dan 144, sampel dipersiapkan untuk uji derajat keasaman dan aktivitas enzim CMC. ase.

Pada tahap kedira, pada jam ke-0 dan 6 diambit sampel sebanyak $1,5 \mathrm{ml}$ dengan menggunakan syringe/sputt steril. Sampel yang didapat kemudian diuji derajat keasaman, aktiyitas enzim CMC-ase dan kadar asam lemak volatil. Sampel yang diperoleh disentrifuge pada kecepatan $15.000 \mathrm{~mm}$. selama 15 menit kemudian filtrat yang diperoleh disimpan dalam refrigerator.

\section{Variabel yang diamati}

Derajat keasaman (pH) cairan rumen. Pengukuran pH dilakukan pada semua sampel yang diambil pada titik inkubasinya dan selanjutnya langsung dilakukan pengukuran derajat keasaman.

Aktivitas enzim carboxy methy! cellulase (CMC-ase), Pengukuran aktivitas enzim CMC-ase ditentukan dergan menghitung jumlah glukosa yang dibebaskan dari reaksi hidrolisis substrat Carboxymethyl cellulase (CMC-ase) pada $\mathrm{pH}$ 5,5 yang diatur dengan penambahan larutan buffer asetat 0,1 $\mathrm{M}$ pH 5,5 (Halliwel et al., 1985). Penentuan kadar glukosa dilakukan dengan reaksi potasium ferrisianida. Hasil pengamatan absorbansi sampel digunakan untuk menghitung besarnya aktivitas enzim $\mathrm{CMC}$ ase yaitu dengan menggunakan persamaan prediksi inversi regresi.

Kadar protein enzim. Kadar protein enzim diperlukan untuk menghitung aktivitas enzim CMC-ase per gram protein enzim: Kadar protein enzim dianalisis berdasarkan metode Lowry dengan mengamati perubahan warna yang terjadi setelah penambahan larutan Lowry (Plummer, 1971). Pengukuran kadat protein enzim terscbut digunakan untuk mengetahui aktivitas enzim $\mathrm{CMC}$-ase pada setiap satuan enzimnya sehingga besarnya 
aktivitas enzim CMC-ase dapat dinyatakan dalam satuan unit per miligram protein enzim.

Kadar protein enzim ditentukan dengan memasukkan data absorbansi sampel setelah direaksikan dengan larutan Lowry B selama 10 menit dan tarutan Lowry A selama 20 menit.

Kadar asam lemak volatil. Asam lemak volatil dianalisis dengan menggunakan metode gas Chromatography (Bachrudin, 1996). Di mana tiap titik pengambilan sampel dianalisa kadar asam lemak volatilnya. Dengan menggunakan mikropipet diambil $2 \mu \mid$ dan dinjeksikan ke dalam kolom pada alat gas Chromatography. Asam lemak yang diukur kadarnya adalah asam asetat, asam propionat dan asam butirat.

\section{Analisis data}

Data yang diperoleh dianalisis statistik variansi dan hasil dilanjutkan dengan perhitungan Duncan Multiple Range Test (DMRT) (Astuti, 1981).

\section{Hasil dan Pembahasan}

Pengaruh penambahan arang aktif (AA) dengan level yang berbeda yaitu I) $0 \%$ A A II)
$0,3 \%$ AA III) $0,6 \%$ AA dan IV) $0,9 \%$ AA pada fermentasi dengan substrat kertas saring sebagal satu-satunya sumber karbon, terhadap aktivitas enzim CMC-ase dan $\mathrm{pH}$ medium fermentasi mikrobia rumen sccara in vitro, pada jam inkubasi ke- 24, 96 dan 144 disajikan pada Tabel 1. Hasil percobaan pada tahap 1 (Tabel 1) menunjukkan aktivitas enzim CMC-ase pada jam inkubasi ke-96 secara rerata meningkat dan menunjukkan perbedaan yang nyata pada masing-masing perlakuan. Pada penambahan AA $0,3 \%$ menumjukkan rerata tertinggi dibanding perlakuan $0 \%, 0,6 \%$ dan $0,9 \%$.

Pengaruh penambahan $0,3 \% \wedge A$ (yaitu penambahan dengan rerata aktivitas $\mathrm{CMC}$-ase yang tertinggi) pada kadar substrat glukosa dan kertas saring yang berbeda yaitu I) $90 \%$ glukosa dan $10 \%$ kertas saring, II) $80 \%$ glukosa dan 20\% kertas saring, dan III) $70 \%$ glukosa dan $30 \%$ kertas saring, IV) $10 \%$ glukosa dan $90 \%$ kertas saring terhadap aktivitas enzim $\mathrm{CMC}$-ase dan derajat kcasaman $\mathrm{pH}$ fermentasi mikrobia rumen secara in vitro pada jam ke-0 dan ke-6 inkubasi disajikan pada Tabel 2.

Tabel 1. Reratu aktivitas enzim CMC-ase ( $\mu$ g D-glukosa/ $\mathrm{mg}$ albumin) dan nilai pH fermentasi mikrobia rumen secara in vitro pada jam inkubasi ke-24, 96 dan 144 (The rate of enzyme CMCase acivities ( $\mu \mathrm{g} D$-gulcose/ $\mathrm{mg}$ albumin) and $p$ Hvalue of rumen microbe fermentation by in vitro at $24^{\text {th }}, 96^{\text {th }}$, and $144^{\text {th }}$ hour of incubation)

\begin{tabular}{|c|c|c|c|c|c|}
\hline \multirow{2}{*}{$\begin{array}{c}\text { Inkubasi jam } \\
\text { ke- } \\
\text { (Incubation } \\
\text { time) }\end{array}$} & \multirow[t]{2}{*}{$\begin{array}{c}\text { Variabel yang } \\
\text { diamati (Variable) }\end{array}$} & \multicolumn{4}{|c|}{$\begin{array}{c}\text { Kadar arang aktif (AA) (Level of Activated charcoal } \\
\text { (AC)) }\end{array}$} \\
\hline & & $0 \%$ & $0,3 \%$ & $0,6 \%$ & $0,9 \%$ \\
\hline \multirow[t]{2}{*}{24} & CMC-ase & $7,52^{a}$ & $7,32^{2}$ & $7,80^{4}$ & $6,90^{\pi}$ \\
\hline & $\mathrm{pH}$ & 6,93 & 6,88 & 6,90 & 7.01 \\
\hline \multirow[t]{2}{*}{96} & CMC-ase & $86,85^{b}$ & $100,38^{2}$ & $32,81^{\mathrm{c}}$ & $13,58^{\mathrm{d}}$ \\
\hline & $\mathrm{pH}$ & 6,45 & 6,70 & 6,85 & 6,80 \\
\hline \multirow[t]{2}{*}{144} & CMC-ase & $25,58^{2}$ & $28,09^{4}$ & $19,43^{\mathrm{a}}$ & $10,21^{\mathrm{A}}$ \\
\hline & $\mathrm{pH}$ & 5,22 & 6,14 & 6,59 & 6,66 \\
\hline
\end{tabular}

${ }^{\text {akel }}$ Superskrip yang berbeda pada baris yang sama menunjukkan perbedaan yang nyata $(\mathrm{P}<0,05)$ (Different superscript at the same raw indicating significant differences $(P<0.05)$ 
Tabel 2. Rerata nilai aktivitas enzim CMC-ase ( $\mu \mathrm{g} \mathrm{D}$-glukosa/ $\mathrm{mg}$ alb) dan nilai pH fermentasi mikrobia rumen secara in vitro dengan kadar arang aktif 0,3\% (Enzyme CMC-ase activities means ( $\mu \mathrm{g}$ D-ghucose/ $\mathrm{mg}$ albumin) and pH rumen microbe fermentation by in witro method using 0.35 activated charcoal $(A C)$ )

\begin{tabular}{|c|c|c|c|c|c|}
\hline \multirow{2}{*}{$\begin{array}{c}\text { Inkubasi Jam } \\
\text { ke- } \\
\text { (lncubation } \\
\text { in hour of }\end{array}$} & \multirow{2}{*}{$\begin{array}{l}\text { Variabel } \\
\text { (Variable) }\end{array}$} & \multicolumn{4}{|c|}{ Perlakuan substrat (Treatment) } \\
\hline & & 1 & II & III & TV \\
\hline \multirow[t]{2}{*}{0} & CMC-ase & $7,09^{3 D}$ & $6,95^{27}$ & $6,95^{20}$ & $4,42^{\mathrm{bP}}$ \\
\hline & $\mathrm{pH}$ & 6,61 & 6,56 & 6,94 & 6,97 \\
\hline \multirow[t]{2}{*}{6} & CMC-ase & $54,07^{84}$ & $93,67^{\text {a4 }}$ & $84,33^{\text {tu }}$ & $60,67^{\circ 9}$ \\
\hline & $\mathrm{pH}$ & 5,68 & 6,16 & 6,54 & 7,37 \\
\hline
\end{tabular}

Superskrip yang berbeda pada baris yang sama menunjukkan perbedaan yang nyata $(P<0,05)$ (Different superscript at the same raw indicating significant differences $(P<0,05)$

${ }^{\mathrm{P}}$ Superskrip yang berbeda pada kolom yang sama menunjukkan perbedaan yang nyata $(\mathrm{P}<0,05)$ (Different superscript at the same column indicating significant differences $(P<0.05)$

\section{Altivitas enzim carboxymethil cellulase}

Aktivitas enzim Carboxymethil cellitase (CMC-ase) diketahui dengan cara mengetahui jumlah glukosa yang dibebaskan dari reaksi hidrolisis substrat CMC. Hasil rerata pengujian aktivitas enzim CMC-ase dapat dilihat pada Tabel 1 dan Tabel 2. Tabel 1. menunjukkan aktivitas enzim pada substrat kertas saring dengan level arang aktif $0 \%$, $0,3 \%, \quad 0,6 \%$ dan $0,9 \%$. Pada jam ke-96 berturut-turut adalah $86,85,100,38,32,81$ dan 13,58 ( $\mu \mathrm{g}$ D-glukosa/ mg protein). Hasil hidrolisis enzimatik dari derivat selulosa (CMC) yang berupa glukosa ini menunjukkan rerata yang paling tinggi pada jam inkubasi ke-96, dan dengan kadar arang aktif $0,3 \%$ menumjukkan rerata aktivitas enzim yang tertinggi. Dengan penambahan AA $0,6 \%$ dan $0,9 \%$ menunjukkan aktivitas yang lebih rendah, hal ini dapat dikarenakan keberadaan AA yang terlalu banyak mengganggu proses fementasi schubungan dengan sifat dari AA yang mampu mengabsorpsi senyawa organik, sehingga ada kemungkinan enzim yang merupakan senyawa organik dengan kadar $\Lambda \mathrm{A}$ $0,6 \%$ dan $0,9 \%$ banyak yang terikat, sehingga aktivitas enzimnya menjadi terganggu.

Substrat yang tersedia untuk mikrobia adalah kertas saring, dimana kertas saring ini dapat dimanfaatkan mikrobia sebagai sumber glukosa untuk sintesis menjadi protein tubuh mikrobia rumen. Aktivitas mikroorganisme rumen dalam mendegradasi pakan dengan penambahan AA $0,3 \%$ menunjukkan hasil yang tertinggi.

Hasil penelitian yang dilakukan Widyantoro et al. (1987) tentang penggunaan kertas saring scbagai sumber giukosa bagi mikrobia, menunjukkan bahwa kertas saring yang terdiri dari selulosa yang difermentasikan dengan mikrobia rumen mencapai puncak konsentrasi glukosa pada jam ke-113 dengan demikian pada jam ke-96 juga masih terjadi proses fermentasi apabila lingkungan mendukung, salah satunya adalah $\mathrm{pH}$ yang akan mempengaruhi berlangsungnya proses fermentasi, Dari hasil penelitian terlihat AA $0,3 \%$ mampu meningkatkan $\mathrm{pH}$ serta aktivitas CMC-ase dibanding kontrol dan perlakuan lainnya.

Pada penambahan $0,3 \%$ AA dengan periakuan substrat yang berbeda (Tabel 2.) pada jam ke- 6 rata-rata mengalami kenaikan aktivitas dibanding pada jam ke-0 dan menunjukkan pengaruh yang nyata terhadap aktivitas enzim $\mathrm{CMC}$-ase pada tiap-tiap perlakuan $(\mathrm{P}<0,05)$, dan pada perlakuan II glukosa $80 \%$ terlihat aktivitas enzimnya secara. 
rerata tertinggi dibanding perlakuan lain. Aktivitas enzim ini menurut Widyantoro et al. (1987) dipenganhi oleh beberapa faktor antara lain suhu, konsentrasi, jenis substrat, $\mathrm{pH}$, lama inkubasi dan jenis mikrobia. Faktorfaktor ini akan mempenganhi produksi glukosa dari fermentasi selulosa dan derivatnya, Hal ini didukung oleh pendapat Enary (1983) yang disitasi oleh Kurniawati (1997) yang menyatakan bahwa pada umumnya produksi dan aktivitas enzim selulase dipengaruhi oleh faktor, substrat, suhu dan $\mathrm{pH}$.

Penambahan AA mampu menetralisir ion hidrogen atau nilai $\mathrm{pH}$ medium fermentasi selulosa, Tingginya nilai $\mathrm{pH}$ tersebut dimungkinkan mampu mempertahankan kestabilan enzim schingga aktivitas enzim CMC-ase meningkat. Penambahan AA dimungkinkan mampu mengabsorpsi ssenyawa-senyawa ion yang akan mempengaruhi kestabilan enzim khususnya struktur gugus aktif enzim tetap terjaga (Shuller, 1980) oleh karena itu penambahan AA mampu meningkatkan aktivitas enzim CMC-ase.

Aktivitas enzim sclulase sangat dipengaruhi oleh pH lingkungan demikian juga enzim $\mathrm{CMC}$-ase sangat dipengaruhi oleh $\mathrm{pH}$, kareru pada penambahan $\mathrm{AA}$ ini $\mathrm{pH}$ masih dalam kisaran normal maka dapat dikatakan enzim CMC-ase dalam keadaan aktif, sehingga dapat memberikan keadaan terjadinya reaksi enzimatik dan fermentasi selulosa secara optimal. Hal ini sesuai pendapat Lowe (1986) yang disitasi oleh Kurniawati (1997) yang menyatakan bahwa aktivitas CMC-ase aktif pada kisaran $3-8$.

\section{Produksi volatile fatty acid}

Pengaruh penambahan arang aktif pada substrat glukosa dan kertas saring dengan penambahan $\mathrm{AA}$ sebesar $0,3 \%$, terhadap produksi volatile fatty acid (VFA) cairan rumen dapat dilihat pada Tabel 3. Dalam fermentasi oleh mikrobia rumen akan menghasilkan berbagai macam asam volatil. Adapun asam penting yang dihasilkan meliputi asam asetat (C2) asam propionat (C3) dan asam butirat (C4).

Dari imbangan rasio $\mathrm{C}_{2}: \mathrm{C}_{3}$ terlihat bahwa dengan penambahan kadar glukosa sampai $80 \%$ memperkecil rasio, hal ini dikarenakan meningkatkan produksi asam propionat sehingga imbangan $\mathrm{C}_{2}: \mathrm{C}_{3}$ menjadi kecil. Pada penambahan glukosa $80 \%$ dan dengan $\mathrm{AA} \quad 0,3 \%$ terlihat mempunyai rasio $\mathrm{C}_{2}$ : $C_{3}$ yang paling rendah dibanding tiga perlakuan yang lainnya. Hal ini dikarenakan dengan adanya AA pada substrat glukosa dengan kadar tinggi mampu mempertahankan $\mathrm{pH}$ antuk aktivitas enzimatis dalam menghidrolisis substrat karbohidrat struktural dan non struktural schingga terjadi pembentukan asam asetat dan juga propionat: Tetapi peningkatan asam $\mathrm{C}_{3}$ lebih tinggi sehingga rasionya menjadi kecil. Pada penambahan glukosa sampai $90 \%$ terlihat bahwa rasio $C_{2}: C_{3}$ dapat dikatakan sama dengan penambahar glukosa $80 \%$ hal ini sehubungan dengan substrat yang difermentasi berupa karbohidrat non-struktural yang tinggi sehingga bakteri yaug memfermentasi gnla lebih cepat dalam fermentasi substrat sehingga terjadi pembentukan asam propionat yang lebih cepat. Tetapi produksi asam asetat lebih rendah sehingga mempengaruhi imbangan $\mathrm{C}_{2}$ : $\mathrm{C}_{3}$ nya,

Rasio antar $\mathrm{C}_{2}: \mathrm{C}_{3}$ dari Tabel 3 diatas dapas dilihat bahwa ada perbedaan nyata $(\mathrm{P}<0,05)$ antara perlakuan glukosa $80 \%$, glukosa $90 \%$ dengan perlakuan glukosa $10 \%$. Hal ini dapat menunjukkan bahwa dengan naiknya kadar propionat dapat menurunkan imbangan $\mathrm{C}_{2}: \mathrm{C}_{3}$. 
Tabel 3. Pengaruh penambahan karbon aktif 0,3\% pada substrat kertas saring dan glukosa terhadap rerata produkst volatile fatty acid (VFA) cairan rumen (Effect of addition active charcoal (AC) $0.3 \%$ addition on wolatile fatty acid production).

\begin{tabular}{|c|c|c|c|c|}
\hline \multirow[t]{2}{*}{ Periakuan (Treatment) } & \multicolumn{4}{|c|}{ Kadar VFA (mol) (Level of VFA (mol) } \\
\hline & $\begin{array}{c}\text { Asetat } \\
(\text { Acetate })\left(\mathrm{C}_{2}\right)\end{array}$ & $\begin{array}{c}\text { Propionat } \\
\text { (Propionate) } \\
\left(\mathrm{C}_{3}\right)\end{array}$ & $\begin{array}{c}\text { Butirat } \\
\text { (Butirate) }\left(\mathrm{C}_{4}\right)\end{array}$ & Rasio $\mathrm{C}_{2}: \mathrm{C}_{3}$ \\
\hline $\begin{array}{c}90 \% \text { glukosa (glucose) } \\
10 \% \text { kertas saring(Fiter } \\
\text { paper) }\end{array}$ & $3,12^{\mathrm{n}}$ & $1,00^{\mathrm{a}}$ & $0,46^{2}$ & $3,28^{6}$ \\
\hline $\begin{array}{c}80 \% \text { glukosa (glucose) } \\
20 \% \text { kettas saring (filter } \\
\text { paper) }\end{array}$ & $4,84^{2}$ & $1,51^{*}$ & $0,54^{4}$ & $3,27^{6}$ \\
\hline $\begin{array}{c}10 \% \text { glukosa (glucose) } \\
90 \% \text { kertas saring (filter } \\
\text { paper) }\end{array}$ & $3,50^{\mathrm{b}}$ & $0,44^{b}$ & $0,27^{\mathrm{a}}$ & $8,36^{\text {ah }}$ \\
\hline $\begin{array}{c}10 \% \text { glukosa (glucose) } \\
90 \% \text { kertas saring (fitter } \\
\text { paper) }\end{array}$ & $5,46^{i}$ & $0,44^{\mathrm{b}}$ & $0,69^{\pi}$ & $16,29^{4}$ \\
\hline
\end{tabular}

\section{Kesimpulan}

Dari hasil penelitian dapat disimpulkan bahwa penambahan arang aktif (AA) mampu mempertahankan kondisi medium fermentasi mikrobia rumen untuk optimal berlangsungnya proses fermentasi yang ditunjukkan dengan hasii fermentasi glukosa dan kertas saring dengan rasio $C_{2}: C_{3}$ pada penambahan A^ $0,3 \%$ sebcsar 3,27 ,

\section{Daftar Pustaka}

Astuti., M. 1981, Rancangan Percobaan dan Analisa Statistika, Bagian II. Fakultas Peternakan. Universitas Gadjah Mada, Yogyakarta.

Bachruddin, Z. 1996. Pengukuran pH dan asam lemak terbang. (VEA) cairan rumen dengan gas chromatografi. Pada: Kursus Singkat Teknik Evaluasi Pakan Ruminansia. Fakultas Petemakan. Universitas Gadjah Mada. Yogyakarta.

Bachruddin, Z. 1999. Pengaruh penambahan arang aktif pada ransum konsentrat tinggi terhadap fermentasi rumen kambing Peranakan Ettawa. Bulctin Peternakan. Universitas Gadjah Mada. Yogyakarta.

Church, D. C. and W.G. Pond, 1982. Basic Animal Nutrition and Feeding $2^{\text {nd }} \mathrm{ed}$, John Willey and Sons. New York.

Church, D. C. 1988. The Ruminant Animal Digestive Physiology and Nutrition. Prentice hall. Engelwood Clifts. New Jersey.

Davies, H.L. 1982. Microbial of the gut. In: Nutrition and Growth Manual. AUIDP.AAUC. Australia.

Garillo, E.P., R. Pradhan and H. Tobioka. 1994. Effect of activated charcoal on ruminal characteristics and blood profiles in mature goats, West Japan. J. Anim Sci. 37. 85 - 89,

Halliwell, G., M.N. Wahab and A.H. Patel, 1985. Chemical composition of endo $1,4-b-D$ - glukanases to cellulolitic in Trichoderma coningi. J. Appl. Bio. 7: $43-45$. 
Trianta, E 1997. Pengarufi penatiobahan konsentrat pada pakan basal jerami padi terladap $\mathrm{pH}$, aktivitas hemisclulolitik dan protein mikrobia pada kerbau dan domba. Skripsi S-1. Fakultas Petectakati, Universitas Gadjah Mada. Yogyakarta.

Kurniawati, A. 1999. Puriftkasi dan karakteristik sellulase yang diproduksi oleh isolat mikrobia selulolitik rumen kerbail. Tesis S-2 Program Pasca Sarjana, Universitas Gadjah Mada. Yogayakarti.

Kuswandi, 1993. Kegiatan mikrobia di rumen dan manipulasinya untuk menaikkan efisiensi produksi temak. Buletin Petemakan 17: 68 - 75, Fakultas Peternakan. Universitas Gadjah Mada. Yogyakarta.

Lohninger, Albert, L. 1997, Dasar-dasar 3 3iokimia. Erlangga, Jakarta.

Plummer, D.T. 1971. An Introduction to Prnctical Biochemistry, Mc. Graw Hill. Ltd. Bombay. New Delhi.
Shuller, M. C. 1980. Utilization and Recycle of Agricultural Waste and Residues. CRC Press. Inc. Boca Raton . Florida.

Sutardi, T. 1978. Intensitas pencemaan pada kerbau. Seminar Ruminansia. $24-25$ Juli 1978. Fakultas Petemakan IPB, Bandung.

Tiliman, A.D. H. Hartari, S. Reksohadiprojo, S. Prawirokusumo dan S. Lebdosoekojo. 1991. Ilmu Makanan Temak Dasar, Gadjah Mada University Press, Yogyakarta

Widyantoro, R. Litomo, M. Socjono. 1987. Studi Pergguman kertas sumber glukosa untuk sintesis protein mikrobia in vitro. Dalam Prosiding Limbah Pertanian Sebagal Pakan dan Manfaat Lainnya.

Witanti, 1992. Pembuatan karbon aktif dari petroleum cokes sebagai penycrap gas. Skripsi Fakultas MIPA. Universitus Gadjah Mada. Yogayakarta. 